4th International Scientific Conference SEC-IASR 2019, Galati, Romania, 7th - 8th June, 2019

\title{
The Importance of Using an Appropriate Methodology for the Development of Speed by Gymnazial Cycle Children
}

\author{
Cristian Ştefan LIUŞNEA \\ https://doi.org/10.18662/lumproc/sec-iasr2019/20
}

How to cite: Liuşnea, C.S. (2020). The Importance of Using an Appropriate Methodology for the Development of Speed by Gymnazial Cycle Children. In S. Marin \& P. Moisescu (vol. eds.), Lumen Proceedings: Vol. 12. 4th International Scientific Conference SEC-IASR 2019 (pp. 182-198). Iasi, Romania: LUMEN Publishing House.

https://doi.org/10.18662/lumproc/sec-iasr2019/20 


\title{
The Importance of Using an Appropriate Methodology for the Development of Speed by Gymnazial Cycle Children
}

\author{
Cristian Ştefan LIUŞNEA ${ }^{1}$
}

\begin{abstract}
The most favorable timeframe for speed development, especially the response rate, is between 6-18 years of age, with the youngest age having the greatest potential, because the basic psychic processes are not stabilized and the analyzers, especially the motor analyzer, can improve their basic functions and especially those related to driving activity. Considering the multitude of factors involved in the manifestation of speed and differentiated age periods in which it is possible to act with increased chances on one or other of the factors, it is necessary to amplify and diversify the exercises and activities meant for the development of the speed, a more careful differentiation of their dependent the age of the students they act on. Only with the observance of an appropriate methodology based on the optimization and the objectivity of the actuation systems used and the objectives pursued at each age-period can be obtained increased results in the development of this important quality, strongly determined by the hereditary dowry.
\end{abstract}

Keywords: methodology; drive systems; speed; exercises; stacks.

1 “Dunărea de Jos “University of Galați, Romania, stef lius@yahoo.com 


\section{Introduction}

The specialists in the school physical education, including Bill Foran [1], says that sports training, which aims to train performance athletes and is conducted according to training principles, is very different from physical activity in the school environment, both through goals, as well as by focusing on the educational and playful aspects of the latter. In this context, continues Fernando Bernal-Reyes, Alejandro Peralta-Mendívil, Hugo Helio Gavotto-Nogales, Lucía Placencia-Camacho [2: 42], the teacher of physical education must know the needs, abilities and possibilities of the students, in order to know how to learn to plan the activity, setting objectives related to the possible progress, according to the particularities of age and exercises that can be done based on the knowledge of the beneficial influence on the student body, the main objective being their health and when scheduling the breaks of recovery of the body after the effort.

At the same time, specialists differentiate between physical capacities and physical qualities (strength, speed, endurance, etc.), the first focusing on potential (natural or acquired possibilities) and development phases, while the second category defines the qualities formed [3]. Also, Juan A. Párraga Montilla, Manuel Delgado Fernández [4] distinguish between basic (primary) or conditional (resistance, force, amplitude of movement) and derived (secondary) physical qualities or results from the conjunction of two or more many qualities (agility, balance, coordination). These authors consider speed as a manifestation resulting from the interaction between force and coordination [4].

In fact, the motor action, simple or complex, is the result of the multiple forms of combining the motor qualities with technical elements. No motor action, no matter how simple its structure, is supported not only by a single motor quality, but by the result of combining in two different proportions two or more qualities or forms of manifestation. The multitude of forms of their combination and interconditioning relationships must be sought at the origin of each motor skill and technical process.

The intercondition between the motor qualities in performing the movement actions is so varied, that each motor quality must also be considered as a determining factor, which conditions the manifestation of the others. In particular, skill and strength show the greatest interconditioning with the other qualities.

While the training and consolidation of the basic motor skills, but especially those specific to the different branches of sport, can generally be carried out only with adequate equipment, on landscaped grounds and in halls, the development of the motor qualities, especially of the force, speed 
and endurance can be done in simple space conditions and with easy-tomake equipment. In any school, even in those that do not have an optimal material base, at any time, the development of the motor qualities can be achieved at the level of the requirements of the school programs. It only requires concern and imagination on the part of the teacher to make, with the help of the students, simple or improvised devices (sand bags, sticks) or by drawing up spaces in which to carry out the activity.

At the same time, specialists make the distinction between learning motor skills, understood as improving performance beyond the initial level and adapting to motor or returning to basic performance, affected by a strong external disruptive factor. Regarding the level of motor qualities, the distinction is made between the level of task execution and the quality of the movement, respectively, the relationship between the two being currently insufficiently understood.

In addition, some of the specialists, such as Lior Shmuelof, John W. Krakauer and Pietro Mazzoni [5: 578] propose the acquisition of motor skills, which can be characterized as a slow reduction in the variability of movement, which is distinguished by learning faster based on models that reduce systematic errors in adaptation paradigms..

\section{Theoretical Background}

Many specialists, as well as sports practice, demonstrate that the level of development of the motor qualities largely determines the fulfillment of the requirements stipulated in the school programs regarding the extension and improvement of the system of knowledge, skills and motor skills in the students. Speed is one of the driving qualities, which develops between 6 and 12 years which corresponds to the early school age and in the pubertal period - 11-12 years. [6: 372], so it is one of the first to be found by specialists, who perceive it semantically, slightly differently, even if there are authors and exclude it from among them, considering it as short-term resistance.

Next, we will review the opinions of the specialists on the definition of speed (or speed) and we will start with Ariel Ruíz Aguilera, Rodríguez López and Dorta Sasco [7: 79, 82] for which speed is "a conditional capacity of the human body, while the concept of speed is proper the mechanics and determines a time of movement of an object in a given space".

Another author, Manfred Grosser [8] thinks of speed is it a pure capacity of the physical condition, identifying four possibilities of manifestation, along with other authors, including it between the conditional 
capacities, next to the resistance and force and between the coordinative ones [8: 13; 9]. On the contrary, Carlo Vittorini [10] considers it a complex capacity. This depends on gender and age, as shown by specialists, such as fig. 1: Grasselt (1984), quoted by M. Grosser [8: 17-18, 32].

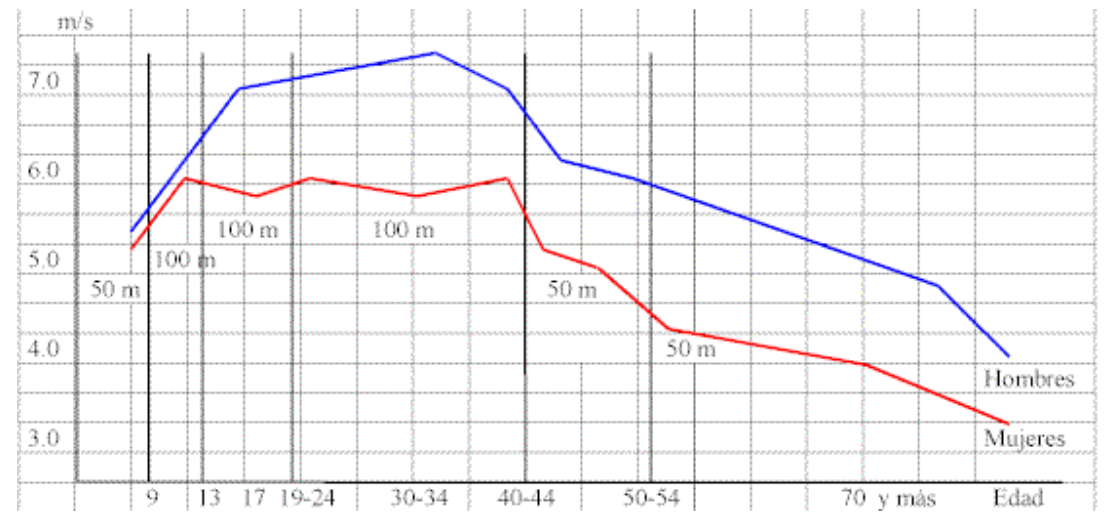

Fig. 1.Evolution of speed by sex and age, at the $100 \mathrm{~m}$ sprint event (Grasselt, 1984)

According to Carlos Álvarez del Villar [11], speed is "the ability of the individual to execute one or different movements as quickly as possible" or "the ability of the subject to perform an activity in minimum time or rather, the ability to travel a distance, greater or less, in a unit of time." The sense of execution of a movement as soon as possible is shared by other authors, including N.G. Ozolin [12], Guenter Frey [13], Manfred Grosser [14], Luis Enrique Ortíz Astúa [15], Jürg Baumberger and Urs Müller, [16, 36], Vladimir M. Zatiorski [17], Manfred Grosser, Stephan Starischka, Elke Zimmermann [18] et al.

Speaking about this motor quality, Rendey Horacio Ortiz Rodriguez [19] states that: "speed is the queen of physical qualities, even though it is dependent on others, as well as strength and endurance. Undoubtedly, bebind the specific manifestation of speed (beyond natural talent), many hours of training are needed in perfecting sports techniques and in developing the other alliances that underlie speed."

At the same time, Vladimir Nikolaevich Platonov [20] considers the speed capabilities of the athlete as being related to the functional properties that allow the execution of the motor actions in a minimum time.

According to Ariel Ruiz Aguilera [21], speed is the conditional capacity, indispensable to perform, in given conditions, motor actions in the shortest possible time. In the same idea, Armando Forteza de la Rosa and Armando y Alfredo Ranzola Ribas [22] defines speed as the ability to perform a motor task in certain situations, in a relatively minimal time or with a maximum frequency. 
In turn, Erwin Hanh [23] defines speed as the ability of the human being to perform motor actions with maximum intensity and under certain circumstances in a minimal time; assuming the pregnancy is short-lived and there is no fatigue.

Jürgen Weineck [24] talks about the determinants of speed: the reaction speed, the acceleration speed, the launch speed and the speed resistance, which other authors had considered to be shapes or types of speed. The same author observes that in children and adolescents (8-16 years), the speed varies over time, because the high plasticity of the cerebral cortex and the natural morphological stability of the nervous system allow the optimal formation of the base in the speed sector [25: 400]. Therefore, its development during this sensitive or critical period [26], will favor an increase of muscular contractility with influence on the speed of sports gestures. The development of the speed therefore depends on the age and personal characteristics of the students and the neuromuscular coordination.

M. López [27] talks about four other factors that influence speed: hereditary, evolutionary and learning factors; sensory-cognitive factors; neuronal and tendon-muscle factors.

The specialists such as Dietrich Harre [28] and Manfred Grosser [8], believe that of the motor qualities, speed is the most difficult and the most difficult to improve compared to other factors, such as strength and endurance. At the same time, we recall that force-dependent parameters reach optimal shape later than speed. [25: 358]

Karl Ernst and Walter Bucher [29: 36] believe that speed can be easily driven in pre-adolescence, as pupils' progress is related to improving their ability to coordinate, the motor activity targeting not only the physical but also the mental field, carried out for short periods, alternatively with periods of recovery, it is necessary to avoid the effort of type resistancespeed, which determines a debt of oxygen and therefore an accumulation of lactic acid. The experts mentioned also believe that the game and the competition can be favorable situations for speed development.

But by analyzing more deeply the way of performing the motor acts and actions, we find that one of the temporal components is precisely the speed with which it is executed. For this reason we can express the execution in qualitative terms (very fast, fast, slow, very slow - generally known as tempo) and quantitative (duration). Most often, the movements are appreciated simultaneously by the spatial and temporal characteristics, making the relation between the duration and the mechanical work performed. The speed of the gesture is determined by the cognitive processes and the will of the respective person. 
Manfred Grosser [8: 14] defines speed in sport as "the ability to achieve, based on cognitive processes, the maximum volitional force and functionality of the neuromuscular system, the maximum reaction rate and movement under certain conditions", which is a psychophysical capacity. Moreover, the same author, is convinced that a sportsman can be considered fast if he is able to "play" at maximum speeds and feel their variations. [8: 9]

For his part, Renato Manno [30] quickly understands a heterogeneous set of components such as: the reaction time of the motor, the speed of each movement and the rhythm of the movements. This has a positive impact on the reaction speed, which can be defined as the whole "information perception - analysis - muscle activation", which is one of the three components of speed with movement speed and gestural frequency. [30].

Juan Manso García, Martín Navarro and J. Acero Ruiz [31: 139], believe that, from a sporting point of view, speed represents "the ability of a subject to perform motor actions in a minimum time and with maximum efficiency". Juan Manuel García Manso [32, 33] complements the definition of speed in relation to other capacities and establishes that it is a hybrid capacity that is conditioned by all other conditional capacities (strength, endurance and mobility or flexibility).

Manuel Delgado [34] is of the opinion that speed is a neuromuscular activity (gestational speed and reaction time), as a speed of nerve impulse transmission, involving the anaerobic anaerobic metabolism and must be developed during primary education, since the coordinating factors and the nerves on which it depends mature before puberty.

Jürgen Weineck [25: 355] contends that the most complete definition of speed is given by M. Grosser [8: 13], who contends that in addition to the physical and coordinative aspects, he also incorporates the physical components: "speed in sport is the ability to obtain, based on cognitive processes, the maximum willpower and based on the functionality of the neuromuscular system, maximum reaction speed and possible movements under certain conditions."

Vladimir Zatziorski [36: 355] defined speed as the ability to perform motor actions under certain conditions and in a minimum time or "an extraordinary complex of varied and complex of capacities, which manifest themselves in different forms in different ways".

According to Juan Torres Guerrero [37], from 8 to 13 years old, speed must be prepared, both responsiveness as speed of movement, but with short distances and through tasks that improve neuromuscular coordination, which is the factor that will produce results better at this age. The cited author is convinced that the speed of the movements in sports exercises is fundamental, because the effectiveness of the execution depends, to a large extent, on the speed with which it is performed. [37] Thus, the 
concept of speed is related to the need to perform a motive action in a minimum time as a primary requirement. There is no speed if there is no requirement to perform the motor action as soon as possible.

Speed depends on a variety of parameters, one of the most significant being the development of muscle strength, because the ability to perform rapid movements with the whole body or some of its parts, is influenced, in particular, by the use of force speed, with a important development in the period 13-15 years [26].

Another parameter to be considered concerns the percentage of muscle fibers in the fast and slow contraction of the subject, which seems to be determined at the beginning of the year, having a certain margin of influence for training. This implies that the insistence, until that age, of the predominantly resistance-based training, can diminish the speed capabilities in the child's future [38].

But, without a doubt, speed depends essentially on genetic constitutional characterization, so there are types of speed and even phases that can be traced under rigorous planning. According to R. Winters [39], among the speed capabilities that are formed earlier, are the ability to react and the ability to execute high-frequency movements, which must begin preschool (early education) training. It should be considered a non-systematic training, based on the forms used in pursuit games, short relays in different situations, as well as a wide range of reaction time exercises in which you have to catch, throw, stop, exit from different positions, etc. [40].

According to Wildor Hollmann and Theodor Hettinger [41], the functional maturation and morphology of the nerve cells reaches the maximum at about 10-12 years, for which it considers that between the ages of 8-12 years there is a sensitive phase for a good developmental time of reaction and a large increase in frequency speed. In these years, we go through a phase of strong development, where the will, the motivation and the concentration allow this quality to work optimally.

Juan Manso García, Martín Navarro and J. Acero Ruiz y Martín [31], in a timely manner we will include all those isolated actions that consist of a single movement, while when it comes to turning movements within a sports action about which we will talk about speed. The speed comprises two forms of the speed of a simple speed movement and the reaction speed [31], and both go to greater or lesser extent in sports orientation. 


\section{Argument of the paper}

The value of speed, of its manifestation forms, is conditioned by several factors: physiological, biochemical, psychological and to a certain extent morphological. Some are heavily influenced by the hereditary structure of each individual and are less perfectible. The biological and mental support of speed are: the mobility of cortical nerve processes; rapid alternation in cortical centers of excitation and inhibition; the rate of transmission of nerve impulses (reaction time); the acuity, the precision of the receiving organs of the signals; optimal rhythm of alternating contractions and relaxations of muscle groups; quality of muscle fiber; the level of development of the other motor qualities (skill, strength, endurance); ability to concentrate and mobilize. Analyzing the problem of speed from a biochemical point of view, we note the conditioning of its value by the ATP and phosphocreatine content of the muscles, the main energy sources that support the speed effort.

Within the physical education lesson for speed development, different exercises and activities can be used such as:

a) exercises with selective influence - stretching, bending, rotating, etc., executed at a fast pace for 5-10 seconds. It develops the speed of execution and the speed of repetition, as well as the sense of rhythm.

b) exercises in the group of front actions and formations, in particular, changes of formation, changes of direction of movement, performed at direct commands, at reverse orders. These exercises positive influence the speed of reaction and execution.

c) sticks and games of movement that demand attention and prompt reactions to different signals (visual, audible or tactile) given by surprise. Develops the reaction speed, the anticipation ability, and repetition speed.

d) exercises and games with the ball, quick throws and catches, catching the thrown ball upwards, catching some balls from the wall (face or back to the thrower), keeping and catching 2-3 balls (inserted in the circuit)) in different formations. Develops all forms of speed manifestation under complex conditions.

e) starts from different positions (standing, lying face to face or back to the direction of travel) at orders given by surprise, by sound or visual signals. Develops reaction speed and repeat speed.

f) exercises from the running school involved in speed running such as the acceleration step, the speed launched step, the low start and the start from the start. It develops running speed as well as other forms of speed.

g) exercises and actions in sports games: fast passes in two, quick kicks at goal, counter-attacking actions, marking, clearing, quick retreat, 
dribbling with the opponent. Develops reaction speed, as well as other forms of speed manifestation under various request conditions.

h) bilateral sports games, carried out under speed conditions: short rounds, on small field.

i) running with acceleration up to 50 meters.

j) running speed over distances of 40-50-60 meters.

k) jumps in gymnastics and some technical elements in sports games.

15-30 meters.

l) running launched with the maximum temperature maintained on

$\mathrm{m})$ alternation of the execution of movements in different times $(1 / 4,2 / 4,3 / 4,4 / 4)$.

n) some force exercises (thrusts, pulls, loosening, throws) of short duration and low load.

In order to obtain positive effects in the direction of speed development, the exercises mentioned above must be known by the students.

The reaction speed is of a purely nervous nature, for example, and considering that at the age of 11 , the nervous system enjoys a great plasticity, during this period it will have to insist a lot, including in the content of the lessons as many exercises, games and sticks in order to increase this kind of speed manifestation. These exercises should be done at the beginning of the lesson so that the students are not physically or intellectually tired. Failure to comply with this law will cause the reaction rate to be altered rather than tending to increase it.

In order to improve the speed of execution, the exercises and the technical procedures of some sports branches can be used, following the continuous increase of the number of repetitions in the same period of time. For example, to increase the speed of execution it is possible to use the handball pass through one of the known processes. The number of wall passes that a student can make at a given time is recorded at the beginning. In the work for developing the execution speed, the number of repetitions in the same unit of time will be required. The duration of the exercise should be set so that at the end of the exercise, the speed does not decrease due to fatigue. Students aged 11-13 can withstand the speed effort for 8-9 minutes.

In the Romanian school, the main exercise (unfortunately sometimes unique) through which one acts to develop the speed of repetition is running. So it is about developing speed in one direction - the one specific to the running test - and with only one exercise (running), although this form of speed manifestation can be developed with the help of other exercises, motion games and application paths. The repetition speed is 
involved in the motor actions that have in their structure cyclic movements that are repeated in rapid succession within a limited time.

In order to improve the running speed, which is indicated in the first and second semesters of the school year, the best exercises are sprints and accelerations on the portions of $15,20,30 \mathrm{~m}$. Both solutions have the advantage that they can be applied frontally (with the whole class), by running groups or with a single group of students. The breaks will be determined by the succession of the working groups or calculated around 46 minutes.

\section{Arguments to support the thesis}

In connection with the development of the speed, the school programs in Romania provide specific instructional-educational objectives for each class and indicate the main exercises and activities, on the basis of which the systems used in the lessons for achieving the objectives are established.

Thus, in classes V-VI the emphasis is on developing reaction speed and developing decision speed. In classes VII-VIII it is foreseen the development of the speed of reaction and of execution, under the conditions of manifesting the capacity of anticipation and decision. Also, at the entire gymnasium cycle, it is also expected to improve the repetition speed under the conditions of keeping the execution frequency.

At the same time with the development of the speed of reaction, execution and repetition, the students will work for the full development of the running speed (displacement). It should be specified that the methodology of developing the running speed in general for children aged $11-12$, in the physical education lesson, uses in principle the same means as the dedicated athletes, excluding from their training the exercises for the development of specific strength and strength.

Also, the dosage of the effort and the form of presentation of the students will be appropriate for their age, sex and degree of preparation, as well as the material conditions of the respective school.

In the dosage of effort, it should be taken into account that the end of the exercise should not be characterized by the decrease in frequency in movements, this being an aspect of fatigue, which will lead to negative results. Between repetitions of up to $30 \mathrm{~m}$, the break will take 2-3 minutes, and between the repetitions of $50 \mathrm{~m}$, the break will be extended up to $5 \mathrm{~min}$. between the series, also, a break of 4-6 minutes will be granted. 


\section{Arguments to argue the thesis}

The problems proposed for study in the paper are:

- addressing the problem of streamlining the process of teaching physical education, at the level of the high school cycle, must be based on the theory and practice of applying the contents of the physical education program, which are appropriate to the interests of pre-adolescents of this age, which positively influences the increase of the interests and motivations of the students for physical education classes.

- the current level of physical training of students in the secondary school cycle is characterized by low indices, due to the poor efficiency of the instructive-educational process of the physical education lessons, whose thematic content is weakly correlated with the material conditions in the schools, as well as with the interests and motivations of students of this age.

- the methodology of applying the educational contents from physical education must have the aspect of interdisciplinary interference, of multilateral pedagogical influence based on the instructional transfer of qualities and skills, thus contributing to the optimization of the instructiveeducational process of lessons and, consequently, to the acquisition of the knowledge of physical education, which is manifested by increasing indices of psycho-motor training and physical development of students in the middle school cycle.

\section{Dismantling the arguments against}

Currently, integrated into the complex content of bodily activities, movement games are considered by specialists as means of physical education with an important training-educational role. They bring a valuable contribution to the fulfillment of the tasks of the physical education of the school, allow the diverse and simultaneous manifestation of the basic or specific motor skills of the moral or character physical qualities.

Offering multiple possibilities of practicing under various conditions of the basic motor skills (running, jumping, throwing, catching, balancing) these favor the wide manifestation of the independence of action, within the limits of certain rules. However, this is conditioned by the student's understanding of the objective pursued, the concern of finding permanently optimal solutions to reach the stated goal.

Due to the fact that it required the application of the motor skills under ever changing conditions, the games of movement allow the development of creativity and initiative. The breaks follow one another 
quickly, which requires rapid mental analysis, short-term mobilization of forces, and orientation in space. Most motion games are played in the form of races and sticks.

The application paths contribute by their great variability and accessibility, to the development of complex motility. They are attractive by their novelty and by the state of emulation they develop. At the same time, they include known movements, which are refined and strengthened by repetition.

The most effective form of effort engagement is the race in the form of sticks, the team trial - single or combined - that takes place over a certain distance, because the participants are in a position to participate quickly, in certain actions under difficult conditions. At the same time, besides the physical qualities and some moral and character qualities are required and developed: the will, the courage, the decision, the collectivist spirit, the selfcontrol, the presence of the spirit, etc.

In parallel with the development of the motor qualities, it is also necessary to follow the correct learning of the technique of execution of the speed run.

From the multitude of methods for speed development, one can successfully use: the sticks and games method; the method of training races; method of disability.

Through a precise, well thought out activity, taking into account all the factors that condition the exploitation of the speed potential of the students, at the level of the high school cycle, remarkable results can be obtained in educating this motor quality-speed. The selection and use of a smaller number of means, but which have a very high efficiency in the preparation of the students, must start from:

- studying the exercises established by the school syllabus per year of studies (age);

- setting the content priorities (semester calendar plan and lesson content);

- the teacher to take permanent care (although the tasks are common - girls, boys) to differentiate the volume of effort;

- the teacher to pay due attention to the mental states required for attention, speed, thinking, imagination, initiative, desire for selfimprovement;

- great importance during training should be given to fixing breaks between efforts.

The introduction of movement games together with specific means of athletics, in the link "development of motor speed qualities", can lead to a more significant increase in terms of student results. At the same time, the 
judicious and highly discerning use of motion games and other lessons of the lesson can have a significant influence on improving the basic motor qualities.

The motor speed "speed" can be improved beneficially both within the normal physical education lessons and within the lessons in which movement games can be introduced, with the following recommendations:

- to introduce movement games, in the development links of the motor qualities, due to their attractiveness, which determines a more active participation of the students and therefore the recording of good results;

- to take into account that the games are well chosen, adapted to the age and development level of the students, so that they can be easily learned, and can be practiced and independently;

- the selected games must be dynamic, diverse and reflect the motor qualities that need to be developed;

- to also take into account that students in the high school cycle, sometimes overworked, also need to play, and this can be easily done in physical education lessons;

- physical education contributes, along with the other disciplines, to the multilateral development of the student, and this must be well understood by the physical education teachers who have the duty to attract them through diverse and attractive activities;

- the physical education teacher must always discover new ways to carry out physical education lessons in the most efficient way, even if this requires much more work from him;

- increasing the attractiveness will make the student to come to the physical education hours, be motivated and want to carry out everything they learn, and independently with their friends..

\section{Conclusions}

The games, the relay race and the application courses provide the students with physical training, sufficient to ensure the basis of the harmonious physical development and the development of the basic motor qualities.

In school, it is good to have an efficient association of the specific and non-specific working methods, of the specific physical training for the training in athletics with the games, the sticks and the application paths. Specific and non-specific training means make up a single unit and cannot be separated. 
Care must be taken, that in the case of the use of games, tips and application paths, to prepare for an emotional load conducive to achieving the best performance, in order not to turn everything into an interesting and attractive playful activity for students but lacking efficiency.

The most effective means proved to be the exercises presented in the form of games and sticks, because it solves much better the tasks followed by observing the characteristics of the nervous system of children of this age. Teaching the means of athletics at this age of 11-12 years in the form of games and sticks facilitates the fulfilment of the final goal, because only through these forms can children reach their maximum limits of motor values, to know these values, to exceed their values, their own sensations of speed, to be able to sustain increased efforts in the conditions of fighting with a concrete opponent.

In view of the content of the activity in the 6th class regarding the development of the motor quality - speed, we propose that:

- all three forms of speed manifestation are targeted in preparation;

- the drive systems used to be differentiated by value groups, but to solve the improvement and development of the speed at this age;

- the race remains one of the means used at this age for speed development.

The use of movement games and sticks in the physical education lessons leads to a faster and more accentuated speed development at this age and makes the lessons more attractive, more enjoyable, more dynamic.

\section{References}

[1] Foran B. Acondicionamiento físico para deportes de alto rendimiento. [Physical conditioning for high performance sports], Barcelona: Hispano Europea; 2007. 368 p.

[2] Bernal-Reyes F, Peralta-Mendívil A, Gavotto-Nogales HH. PlacenciaCamacho L. Principles of sports training for improving the physical capacity. Biotecnia. In Revista de Ciencias Biológicas y de la Salud. Universidad de Sonora; 2014, 16(3):42-49.

[3] Castañer Balcells M, Camerino Foguet O. La Educación Física en la enseñanza primaria. Una propuesta curricular para la Reforma. [Physical Education in primary teaching. A curricular proposal for the Reform], 2th ed. Mexico: INDE; 2008. $251 \mathrm{p}$.

[4] Párraga Montilla JA, Delgado MF. El enfrentamiento deportivo análisis conceptual y ámbitos de aplicación, [The confrontation of sports conceptual analysis and areas of application] In Párraga Montilla JA, Sánchez Zagalaz ML. (ed.). Reflexiones sobre educación física y deporte en la edad escolar. Universidad de Jaén: Servicio de Publicaciones; 2000. pp. 17-34. 
[5] Shmuelof L, Krakauer JW, Mazzoni P. How is a motor skill learned? Change and invariance at the levels of task success and trajectory control. In Journal Neurophysiology, 2012 Jul 15; 108(2): 578-594. Weineck J. Biologie du sport. [Sports biology] Paris: Vigot; 1992. 788 p.

[6] Ruíz Aguilera A, López RA, Dorta SF. (ed.) Metodología de la Enseñanza de la Educación Física. [Teaching methodology of Physical Education], Tomos I y II. Ciudad de La Habana: Editorial Pueblo y Educación; 1986. 242 p.

[7] Grosser M, Renner Th. Schnelligkeitstraining. Grundlagen, Methoden, Leistungssteuerung, Programme für alle Sportarten (blvsportwissen). [Speed training. Basics, Methods performance control. Programs for all sports (knowledge sports)] München: BLV Verlang; 1991. 199 p.

[8] Grosser M, Simon W, Lledó I. Entrenamiento de la velocidad. Fundamentos, métodos y programas. [Speed training. Basics, methods and programs] Barcelona: Ediciones Martinez Roca; 1992. 220 p.

[9] Vittori C. Ipotesi di un modello ritmico della corsa dei $100 \mathrm{~m}$. e sua utilizzazione come metodo di controllo del'allenamento. [Hypothesis of Rhythmic model of the $100 \mathrm{~m}$ race and its use as a training control method]. Atleti ca studi. 1986 Nov-Dic, 6 (6): 451-456.

[10] Álvarez del Villar C. La preparación física del fútbol basada en el atletismo. [The physical preparation of the football based on athletics], Madrid: S.L. Gymnos; 1985. 841 p.

[11] Ozolin NG. Metodica antrenamentului sportiv. [Sports training methodology], Bucharest: Stadion; 1972; 377 p.

[12] Frey G. Zur Terminologie und Struktur physischer Leistungsfaktoren und motorischer Fähigkeiten. [Terminology and structure of physical performance factors and motor skills] In Leistungssport. 1977; 7(5):339-362.

[13] Grosser, M. Ansätze zu einer Bewegungslehre des Sports. [Approaches to a movement theory of sport]. In Sportwissenschaft; 1978, 8: 370-392.

[14] Ortiz Astúa LE. Metodología del entrenamiento deportivo. [Sports training metodology] "Memoria de curso". Universidad Nacional. Costa Rica: Heredia; 1991. $91 \mathrm{p}$.

[15] Baumberger J, Müller U. 4.-6. Schuljahr [4th-6th School year], Bern: Lehrmittel Sporterziehung Band 4, 2005, 271 p.

[16] Zatiorski VM. Ştiinţa şi practica antrenamentului de forţă. [The Science and practice of Strength training]. Bucharest: High performance sport. National Sports Agency. I.N.C.S.; 2005. 260 p.

[17] Grosser M. Starischka S, Zimmermann E. Principios del Entrenamiento Deportivo. [Principles of Sports Training], Barcelona: Ediciones Martinez Roca; 1992. 192 p.

[18] Ortiz Rodriguez RH. Tenis: Potencia, velocidad y movilidad. [Tennis: Power, speed and mobility], Barcelona: Inde; 2004; 272 p.

[19] Platonov VN. Teoryya metodolohyya y sportyvnayapodhotovka [Theory and Methodology of Sports Training], Kiev: Vyshchoshk, Raduga. 1984; 336 p 
[20] Ruiz Aguilera A. Metodologia de la ensenanza de la educacion fisica. [Methodology of teaching physical education], Cuba: Editorial Pueblo y Educacion; 1986. 210 p.

[21] Forteza A, Ranzola A. Bases metodológicas del entrenamiento deportivo. [Methodological bases of sports training], La Habana, Cuba: Editorial Científico-Técnica; 1986. 84 p.

[22] Hahn E. Entrenamiento con niños. Deportes-Técnicas. [Training with children Sports-Techniques ] Barcelona: Martínez Roca M. Roca; 1988. 168 p.

[23] Weineck. J. Entrenamiento óptimo. [Optimal training]. Barcelona: Hispano Europea. 1988. 544 p.

[24] Weineck J. Entrenamiento Total. Paidotribo. [Total training]. Barcelona España; 2005. 688 p.

[25] Mero A. Power and speed training during childhood. In E. van Praagh (ed.) Pediatric anaerobic performance. Champaign, Ill: Ed. Human Kinetics. 1998, pp. 241-267.

[26] López M. Desarrollo y Rendimiento Motor desde el nacimiento Hasta la Tercera Edad. [Motor Development and Performance from birth to senior citizen] In XV Congreso Panamericano de Educación Física. Lima Perú. 1995. Quoted by López Ochoa S; Fernández Gonzalo R., De Paz Fernández J.A. Evaluación del efecto del entrenamiento pliométrico en la velocidad / Effect of plyometric training on sprint performance. Revista Internacional de Medicina y Ciencias de la Actividad Física y el Deporte; 2014, 14(53): 89-104.

[27] Harre D. Teoría del Entrenamiento Deportivo. [The Sports Training Theory] Ciudad de La Habana: Editorial Científico - Técnica, Buenos Aires: Stadium; 1989. 395 p.

[28] Ernst K, Bucher W. Eclairages théoriques. Education physique [Theoretical clarifications. Physical Education], Manuel 1. 2e edition. Berne, Suisse: Commission fédérale de sport; 2000. 244 p.

[29] Manno R. Fundamentos del entrenamiento deportivo. [The Fundamentals of sport training], Paidotribo. Cuba: Ministerio de Cultura; $1991.300 \mathrm{p}$

[30] García Manso JM, Navarro Valdivielso M, \& Ruiz Caballero JA, Martín R. Entrenamiento de la Velocidad. [Speed training], Madrid: S.L. Editorial Gymnos. 1997; 400 p.

[31] García Manso JM, Navarro Valdivielso M, Ruiz Caballero JA, \& Martin Acero R. La Velocidad: La Mejora del Rendimiento en Deportes de Velocidad. [Speed: Improving Performance in Speed Sports]. Madrid, España: Gymnos, Editorial Deportiva, S. L. 1998; 316 p

[32] García Manso JM, Navarro Valdivielso M, \& Ruiz Caballero JA. Bases Teóricas del Entrenamiento Deportivo (Principios y Aplicaciones). [Theoretical foundations of sport training. (Principles and applications)] Madrid, España: Gymnos, Editorial Deportiva, S. L.; 1996.518 p.

[33] García Manso JM. La velocidad: La mejorad el rendimiento en los deportes de velocidad. [Speed. Improved performance in speed sports] Madrid: Gymnos; 1998. $288 \mathrm{p}$. 
[34] Delgado M. El entrenamiento de las capacidades físicas en la enseñanza obligatoria. [Physical skills training in compulsory education], In Revista Habilidad Motriz. 1997; 9: 15-25.

[35] Zatsiorsky VM, Spivak M. Les qualités physiques du sportif: (bases de la théorie et de la méthodique de l'éducation). [The physical qualities of the sportsman: (bases of theory and method of education)] Moscou: Culture Physique et Sport; 1966. 146 p.

[36] Torres Guerreros J. Teoría y práctica del entrenamiento deportivo. Consideraciones didácticas. [Theory and practice of sport training. Didactic considerations] Granada: Armilla, Imprenta Proyecto sur Rosillos; 1996. 364 p.

[37] Morente A. Estudio de la velocidad. [Speed study] In J. Vicente Mora. Teoría del Entrenamiento y Acondicionamiento físico. [Theory of Training and Physical Conditioning] Sevilla: Editorial Wanceulen. 1995.

[38] Winters R. Las fases sensibles: Orientaciones generales, nociones y datos practices sobrelas fases sensibles. [The sensitive phases: General guidelines, notions and practical data on the sensitive phases], In Stadium. 1987; 1627: 200-205.

[39] Lizaur P, Martín NY, Padial P. La formación y desarrollo de las cualidades físicas. [The formation and development of the physical qualities]: In J. A. Antón (Editor). Entrenamiento deportivo en la edad escolar. Málaga: UNISPORT; 1989. pp. 61-88.

[40] Hollmann W, Hettinger T. Sportmedizin. Arbeits und Trainingsgrundlagen. [Sports medicine. Basics of work and training] Schattuer. SttutgartSchattauer. Nueva York; 1980. 697 p. 